University Analytical Service Center for conducting elementary analyses and Miss Yuko Tomita for carrying out infra-red spectra measurements.

\section{Literature:}

1) F. Shmidt, Angew. Chem. 64, 536 (1952).

2) R. C. Mehrotra, I. D. Verma, J. LessCommon Metal. 3, 321 (1961).

3) A. Yamamoto, S. Kambara, J. Inorg. Nucl. Chem. 21, 58 (1961).
4) R. C. Mechrotra, J. Prak. Chem. 10, 247 (1960)

5) S. Kambara, A. Yamamoto, The 10th Annual Meetings of Chem. Soc. of Japan (1957).

6) W. Dasler, C. D. Bauer, Ind. Eng. Chem. 18, 52 (1946).

7) J. Nelles, U.S. Pat 2, 187, 821 (1946).

8) J. Goldenson, Anal. Chem。 25, 1723 (1953).

9) S. Kambara, A. Yamamoto, J. Chem. Soc. of Iapan。, Pure Chem. Sec., (Nippon Kagaku Kaishi), 80, 1239 (1959); V. H. Zettler, C. A. Brown, J. Phys, Chem. 61, 1174 (1957).

10) C. G. Barraclough, J. Lewis, R. S. Nyholm, J. Chem. So c. 1959, 3552

11) R. Speer, J. Org. Chem. 14, 655 (1949).

\title{
Studies on the Electrolysis of Gypsum
}

\author{
S. NAGESWARA* \\ Department of Chemistry, University of Mysore, \\ Mysore-2, India
}

Received April 9, 1965

Sulphuric acid was made by electrolysis of solution of Gypsum, using a glass vessel of litre capacity and a porous pot to separate anode and cathode. Graphite rods and platinum foil were used as electrodes. Saturated solution of Gypsum was taken in both the chambers. The solution was stirred to maintain uniform concentration and the acid formed was estimated at the intervals of 30 (thirty) minutes. Current density and voltage were recorded by using a sensity ammeter and voltmeter and after the experiment the porous pot was cleaned. The experiment was carried out at temperatures $26 \pm 1^{\circ} \mathrm{C}, 30 \pm 1^{\circ} \mathrm{C}, 40 \pm 1^{\circ} \mathrm{C}$ and $50 \pm 1^{\circ} \mathrm{C}$ using thermostatic copper hot plate. It has been found from the experiments that the

* Present addiress: Department of Chemistry, Central College,

Bangalore University, Bangalore, India 
concentration of sulphuric acid was very low since the solubility of Gypsum is 2 grams in a litre of water at room temperature. Further it has been noticed that calcium hydroxide deposits on the cathode during the course of electrolysis and thereby hinders the flow of current. At higher temperature sulphuric acid decomposes giving oxygen and hydrogen. The solubility of Gypsum also decreases gradually as the concentration of calcium hydroxide increase during the course of electrolysis and thereby the formation of sulphuric acid also decreases.

\section{Introduction}

Electrolysis of a salt solution to get acid and base solution is very interesting from industrial point of view. Large deposits of gypsum are available in India and utilisation of gypsum as raw material for the manufacture of sulphuric acid has been studied by various workers. $\left.{ }^{1)}, 2\right), 3$ )

The present communication gives an account of the electrolytic behaviour of gypsum and an attempt to produce sulphuric acid from Gypsum.

\section{Experimental Procedure}

A glass vassel of litre capacity was used as the cell.' Graphite rods and platinum foil were used as electrodes. The electrolytic reaction can be expressed as

$$
\mathrm{CaSO}_{4}+\mathrm{H}_{2} \mathrm{O}=\mathrm{CaO}+\mathrm{H}_{2} \mathrm{SO}_{4}
$$

The cell was divided into two compartments by means of porous porcelain. Saturated solution of calcium sulphate was introduced in both chambers. The electrolysis was started 30 minutes after the cell was filled with the solution. Electrolysis was conducted at temperatures as shown in tables. During the electrolysis the solution was stirred to maintain uniform concentration. The formation of sulphuric acid was recorded at every half an hour. $10 \mathrm{~m} l$ of sulphuric acid was taken from the anode chamber by using previously dried pipette. Current density and voltage were recorded by using a sensitive ammeter and voltmeter.
After each run porous porcelain pot was washed with nitric acid and water by applying suction and used for the next run.

\section{Results and Considerations}

It can be seen from the results shown in tables 1 to 4 that the concentration of sulphuric acid obtained is very low. This is due to the low solubility of gypsum in water ( 2 grams per litre at $25^{\circ} \mathrm{C}$ ). Calcium hydroxide deposited on the cathode because of its low solubility and hindered current flow appreciably. At higher temperatures, current is utilised for the liberation of oxygen, hydrogen. Solubility of gypsum in

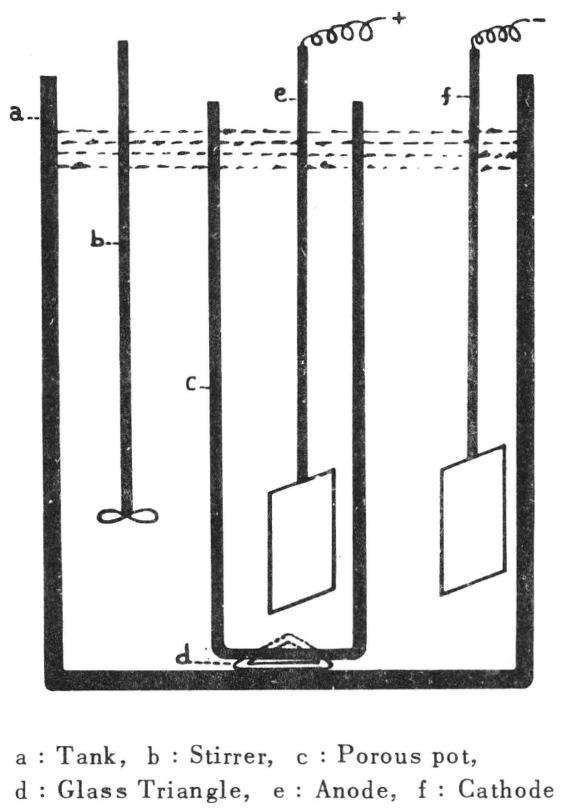

Fig. 1 Diagram of Apparatus. 
Table 1

Electrode, Pt., Surface area of electrode $26.52 \mathrm{~cm}^{2}$, temperature, $26 \pm 1^{\circ} \mathrm{C}$, bath voltage, $4 \mathrm{~V}$

\begin{tabular}{c|l|l|c}
\hline $\begin{array}{c}\text { Duration } \\
\text { of } \\
\text { electrolysis } \\
\text { hr }\end{array}$ & $\begin{array}{c}\text { Current } \\
\text { A }\end{array}$ & $\begin{array}{c}\text { Formation } \\
\text { of acid } \\
(\%)\end{array}$ & $\begin{array}{c}\text { Current } \\
\text { effici- } \\
\text { ency (\%) }\end{array}$ \\
\hline $1 / 2$ & 0.024 & 0.0098 & 0.22 \\
1 & 0.024 & 0.02462 & 0.23 \\
$11 / 2$ & 0.03 & 0.02941 & 0.16 \\
2 & 0.03 & 0.05542 & 0.17 \\
$21 / 2$ & 0.03 & 0.05391 & 0.15 \\
3 & 0.03 & 0.07352 & 0.15 \\
\hline
\end{tabular}

Table 2

Electrode, Pt., Surface area of electrode $26.52 \mathrm{~cm}^{2}$, temperature $30 \pm 1^{\circ} \mathrm{C}$, bath voltage, $4 \mathrm{~V}$

\begin{tabular}{l|l|l|l}
\hline \multicolumn{1}{c|}{$1 / 2$} & 0.025 & 0.0098 & 0.04774 \\
1 & 0.025 & 0.02335 & 0.2375 \\
$11 / 2$ & 0.025 & 0.03430 & 0.2205 \\
2 & 0.03 & 0.0441 & 0.1671 \\
$21 / 2$ & 0.032 & 0.07350 & 0.1967 \\
3 & 0.036 & 0.08818 & 0.1641 \\
\hline
\end{tabular}

Table 3

Electrode, Pt., Surface area of electrode $26.52 \mathrm{~cm}^{2}$, temperature $40 \pm 1^{\circ} \mathrm{C}$, bath voltage, $4 \mathrm{~V}$

\begin{tabular}{l|l|l|l}
\hline \multicolumn{1}{c|}{$1 / 2$} & 0.038 & 0.0245 & 0.3449 \\
1 & 0.04 & 0.0392 & 0.2491 \\
$11 / 2$ & 0.044 & 0.0588 & 0.2140 \\
2 & 0.044 & 0.0882 & 0.2279 \\
$21 / 2$ & 0.044 & 0.098 & 0.1906 \\
3 & 0.044 & 0.1127 & 0.1713 \\
\hline
\end{tabular}

Table 4

Electrode, Pt., Surface area of electrode $26.52 \mathrm{~cm}^{2}$, Temperature $50 \pm 1^{\circ} \mathrm{C}$, bath voltage, $4 \mathrm{~V}$

\begin{tabular}{l|l|l|l}
\hline \multicolumn{1}{c|}{$1 / 2$} & 0.04 & 0.0342 & 0.61 \\
1 & 0.04 & 0.04894 & 0.32 \\
$11 / 2$ & 0.042 & 0.0704 & 0.2754 \\
2 & 0.043 & 0.48308 & 0.2335 \\
$21 / 2$ & 0.043 & 0.09840 & 0.1923 \\
3 & 0.044 & 0.09961 & 0.1867 \\
\hline
\end{tabular}

Table 5

Electrode, Pt., Surface area of electrode $26.52 \mathrm{~cm}^{2}$, temperature $26 \pm 1{ }^{\circ} \mathrm{C}$, bath voltage, $5 \mathrm{~V}$

\begin{tabular}{l|l|l|l}
\hline \multicolumn{1}{c|}{$1 / 2$} & 0.03 & 0.0249 & 0.440 \\
1 & 0.04 & 0.03430 & 0.22 \\
$11 / 2$ & 0.06 & 0.04894 & 0.13 \\
2 & 0.07 & 0.7347 & 0.0706 \\
$21 / 2$ & 0.08 & 0.08261 & 0.908 \\
3 & 0.09 & 0.09819 & 0.072 \\
\hline
\end{tabular}

Table 6

Electrode, Carbon, Surface area of electrode $81 \mathrm{~cm}^{2}$, temperature $26 \pm$ $1^{\circ} \mathrm{C}$, bath voltage $4 \mathrm{~V}$

\begin{tabular}{l|l|l|l}
\hline \multicolumn{1}{c|}{$1 / 2$} & 0.04 & 0.04900 & 0.7 \\
1 & 0.045 & 0.05394 & 0.3 \\
$11 / 2$ & 0.05 & 0.06855 & 0.21 \\
2 & 0.05 & 0.07832 & 0.13 \\
$21 / 2$ & 0.05 & 0.08818 & 0.15 \\
3 & 0.05 & 0.1226 & 0.16 \\
\hline
\end{tabular}

Table 7

Electrode, Carbon Surface area of electrode $81 \mathrm{~cm}^{2}$, temperature $30 \pm$ $1^{\circ} \mathrm{C}$, bath voltage, $4 \mathrm{~V}$

\begin{tabular}{l|l|l|l}
\hline \multicolumn{1}{c|}{$1 / 2$} & 0.05 & 0.04900 & 0.5 \\
1 & 0.06 & 0.07345 & 0.31 \\
$11 / 2$ & 0.065 & 0.09751 & 0.21 \\
2 & 0.07 & 0.1153 & 0.18 \\
$21 / 2$ & 0.075 & 0.1321 & 0.11 \\
3 & 0.08 & 0.1504 & 0.12 \\
\hline
\end{tabular}

Table 8

Electrode, Carbon, Surface area of electrode $81 \mathrm{~cm}^{2}$, temperature $40 \pm$ $1^{\circ} \mathrm{C}$, bath voltage, $4 \mathrm{~V}$

\begin{tabular}{l|l|l|l}
\hline \multicolumn{1}{c|}{$1 / 2$} & 0.05 & 0.0440 & 0.4764 \\
1 & 0.05 & 0.0588 & 0.2717 \\
$11 / 2$ & 0.06 & 0.07350 & 0.1966 \\
2 & 0.065 & 0.0783 & 0.1724 \\
$21 / 2$ & 0.07 & 0.882 & 0.1080 \\
3 & 0.085 & 0.12225 & 0.09638 \\
\hline
\end{tabular}


Table 9

Electrode, Carbon, Surface area of electrode $81 \mathrm{~cm}^{2}$, temperature $50 \pm$ $1^{\circ} \mathrm{C}$, bath voltage, $4 \mathrm{~V}$

\begin{tabular}{l|l|l|l}
\hline \multicolumn{1}{c|}{$1 / 2$} & 0.05 & 0.049 & 0.5311 \\
1 & 0.058 & 0.0539 & 0.2362 \\
$11 / 2$ & 0.065 & 0.05838 & 0.1256 \\
2 & 0.075 & 0.098 & 0.1486 \\
$21 / 2$ & 0.085 & 0.1225 & 0.1234 \\
3 & 0.085 & 0.1470 & 0.1157 \\
\hline
\end{tabular}

calcium hydroxide decreases as the concentration of calcium hydroxide increases during the electrolysis and thereby the formation of sulphuric acid also decreases.
Acknowledgem ent

The author's grateful thanks are due to Dr. G. Narayan for suggesting the problem and for his keen interest in this work.

\section{Literature:}

1) E. Martin, Fro Pat., C.A. 710, 068 (Jan. 28, 1931).

2) E. Martin, Ger. Pat. 548, 367 (March 37, 1931).

3) Manufacture of cement and sulphuric acid from anhydrite I.G. Farbentabrik, Wolfen, B.I.O.S. Final. Report No.678 item No. 22 London, British intelligence objectives sub-committee.

4) Solubilities, Inorganic and Metal Organic compounds. A scidell.

\title{
Galvanostatic Determination of Kinetic Parameters of Electrode Reaction with Generation of a Reactant in Situ*
}

\author{
Shinobu Toshima*, Yutaka OKInAKa** and Hiroshi OKAnIwa* \\ *Department of Applied Chemistry, Faculty of Engineering, \\ Tohoku University, Sakurakoji, Sendai \\ ** Bell Telephone Laboratories, Whippany, New Jersey, \\ U.S.A.
}

Received May 4, 1965

\begin{abstract}
It is shown that kinetic parameters of some simple, fast electrode reactions of the type $\mathrm{Ox}+\mathrm{ne}=\mathrm{Red}$, where Red is soluble in the solution or in the mercury electrode, can be determined by the galvanostatic method with a solution initially containing only the substance $O x$, the substance Red being generated in situ during electrolysis, provided that the electrode reaction involves only a single rate-determining step.
\end{abstract}

* This work was presented in part at the 31 st Annual Meeting of The Electrochemical Society of Japan, 1964 and printed in Denki-kagaku 33, 19 (1965). 